\title{
Escenografía barroca. El tabernáculo de los Churriguera de la Catedral Nueva de Salamanca
}

\author{
CASAS HERNÁNDEZ, Mariano \\ Universidad Pontificia de Salamanca, Salamanca, 2018
}

El profesor de historia del arte, Mariano Casas, en su libro Escenografía barroca, ha reconstruido las formas y el sentido de un hito perdido de la arquitectura hispana, cuya historiografía venía poniendo de relieve distintos problemas de la investigación. Se trata del tabernáculo de los hermanos Churriguera, un aparato escénico, hoy desaparecido, que modificó la configuración de la llamada Catedral Nueva de Salamanca en el primer tercio del siglo XVIII.

El libro ha sido recién publicado a cargo de la Universidad Pontificia, donde el autor se licenció en Teología. Pero es fruto de una parte de su tesis doctoral de historia del arte (2013) dedicada al tabernáculo; ya había sido estudiado en su trabajo de fin de grado (2008) en la misma Universidad de Salamanca, donde el profesor Casas ejerce actualmente y donde pudo compartir su labor con la dirección del Museo Catedralicio. Esta dedicación interdisciplinar ha propiciado una perspectiva amplia y profunda de la obra de arte religioso. Así lo demuestran las fuentes que ha exhumado, la inmersión en la arquitectura y el archivo catedralicio, y el aparato de notas que reúne bibliografía selecta y que completa el cuerpo del libro diversificando sus argumentos. Las fotografías que lo ilustran a color reúnen en esta nueva obra los restos desmembrados de aquel escenario litúrgico destruido, pese a la dispersión y escasez de documentos, prejuicios y silencios de una espesa historiografía y otros obstáculos que ha superado el estudio para recomponer aquel teatro barroco.

El autor ha decantado la «mezcla de tradiciones y sensibilidades» que hicieron surgir hacia 1733 en Salamanca una catedral distribuida al modo hispano pero con la cabecera centralizada mediante un tabernáculo influido por el gusto novohispano. En términos de Casas, «la trama semántica» de esta iglesia se organizaba en una «sucesión dialógica» de «lugares fuertes» acentuados por la iconografía, articulados en dos bloques complementarios de significación: el «eje axial» que comenzaba en el pórtico oeste y seguía por coro, cimborrio y tabernáculo para terminar en el «telón de fondo» de la capilla del Cristo de las Batallas, y el bloque de la cabe-

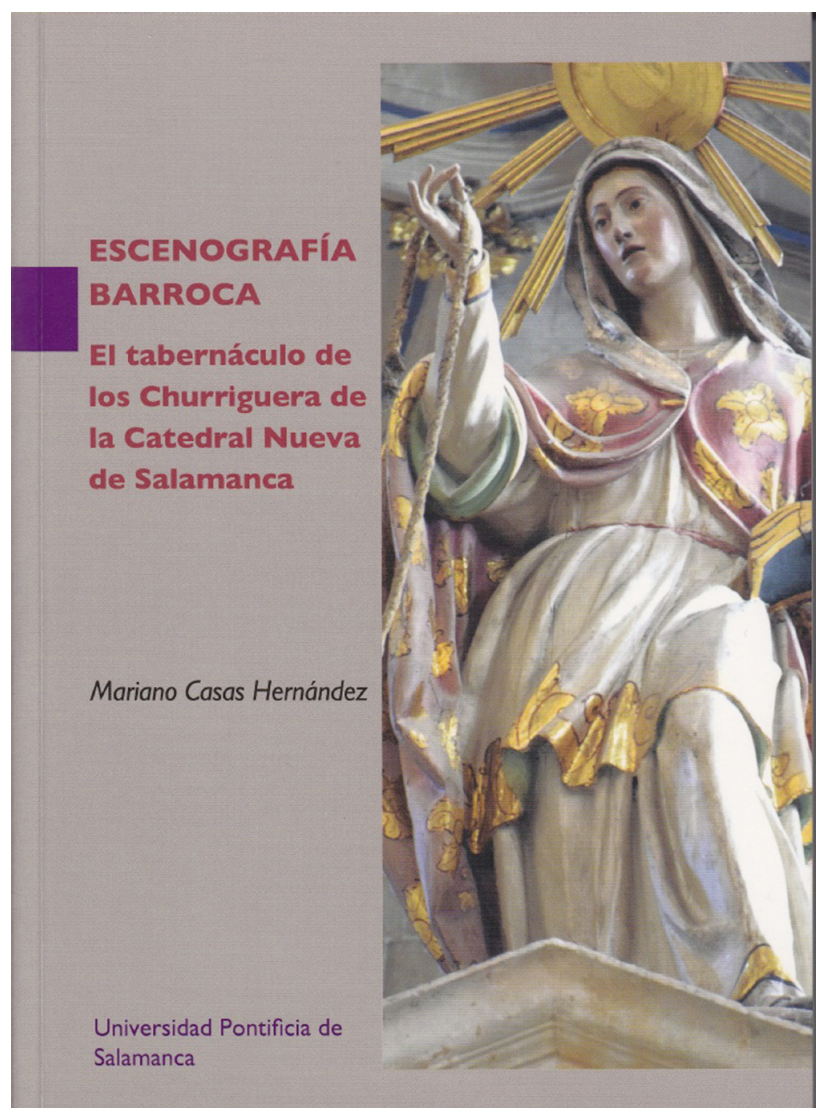

cera centralizada que se engranaba a este eje focalizándose por medio del tabernáculo.

El estudio ha corroborado que, en principio, la traza de la catedral del siglo XVI respondía a la tradición compostelana. Su cabecera fue modificada en reflejo de las innovaciones que Juan de Herrera puso en práctica en el templo de Valladolid, obedeciendo a la organización de espacios litúrgicos que se imponía en las iglesias de España tras el Concilio de Trento. Pero la planta salmantina se elevó en un alzado tardogótico para satisfacer el gusto de su promotor, el cabildo, conservador de la idea de unidad estilística del templo. Sobre restos documentales, como la planta dibu- 
jada por García de Quiñones (conservada en Zaragoza), se comprueba que aquella enorme cabecera era un lugar de culto, no de tránsito, no tenía capilla mayor, y albergó en el siglo XVIII un tabernáculo, mientras el coro se instaló, según la costumbre hispana, en la nave central del templo. El ornamento de bóveda y muros del presbiterio remarcaba el «epicentro del culto» para solventar la «aparente incongruencia espacial» del edificio respecto a los modelos históricos. El tabernáculo, del tipo de las arquitecturas efímeras barrocas, era el sagrario, y el tramo abovedado sobre él, hacía de baldaquino en una «obra total».

El artefacto escenográfico que componía el tabernáculo, mixto en su tipología, tenía además un tamaño insólito en la Península. Casas lo ha comparado con el diseño herreriano de San Isidro de Madrid y los grandes cipreses de las catedrales mexicanas. A partir de estudios de Joaquín Lorda, ha sugerido que, si Juan de Herrera pudo conocer el proyecto del ciprés angelopolitano a través de su promotor (el obispo Palafox, viajero desde Puebla a la corte española), también pudieran asemejarse San Isidro y la catedral de Salamanca debido al interés que tenían los Churriguera en los proyectos de Herrera, y al fuerte contacto del cabildo salmantino con las sedes novohispanas.

La traza del tabernáculo fue presentada por Alberto Churriguera al capítulo de Salamanca en 1726, pero no se conserva. Sin embargo, ha podido estimarse la dependencia estilística del artefacto para con la arquitectura y traza del coro, diseñado por el hermano de Alberto y predecesor al mando de la reforma catedralicia, Joaquín Churriguera, quien no pudo ver terminado su proyecto al morir en 1724. El examen de los documentos también ha permitido detallar la cronología de los procesos de contratación y ejecución de la obra, sus técnicas y materiales, y desgranar el variado grupo de profesionales coordinados por los Churriguera y José de Larra (maestro escultor).

El tabernáculo se colocó y se celebró en la catedral en 1733. La interpretación de las huellas que dejó en la arquitectura y fuentes escritas y gráficas, ha permitido reconstruir su forma simbólica y funcional en la liturgia: de planta cuadrangular, con un altar a cada lado, elevado sobre siete gradas, tres cuerpos y el remate. Esta estructura resaltaba el sagrario (su puerta de pintura y orfebrería pudo pasar al tabernáculo de Gavilán Tomé). En el primer cuerpo, doce doctores de la Iglesia esculpidos en bulto redondo personi- ficaban un discurso católico, peculiar pero ortodoxo. Sobre este se ubicaba la custodia. En el centro, la escultura de la Virgen Asumpta se elevaba hacia las de la Trinidad, y la alegoría de la Religión se exaltaba en el remate. El tabernáculo representaba «la gloria divina y la perfección» con un mensaje iconográfico ideado por un cabildo que promocionaba así su versión de la historia de la Iglesia y afianzaba su posición en el debate de los dogmas que regían el programa: "la presencia real de Cristo en los dones del altar, los denominados privilegios marianos (entonces opiniones pías) y el triunfo esclarecido de la fe católica sobre el resto de divisiones eclesiales (fundamentalmente las facciones protestantes y ortodoxas)».

Llevando la investigación documental más allá del año en que se celebra la construcción, se informa de que, en 1734, el mecanismo que subía el corpus al tabernáculo ya resultaba ineficiente. En 1745 el capítulo decide desmontarlo, y ello ha denotado al autor mentalidades y gustos diferentes a los que una vez promovieron aquel artefacto barroco. Fue removido, y sus esculturas y materiales se donaron o vendieron y se reutilizaron en otros lugares que se recopilan en el libro. De esta manera el análisis capta distintos grados de influencias de la obra, ulteriores en su proceso constructivo y en el marco arquitectónico que la albergaba (se señala la Colegiata de Toro como uno de los edificios que se revistieron con estos «despojos», con la escultura de la Virgen).

La interpretación semántica de las formas define la obra como «patentización de la expresión religiosa del primer tercio del siglo XVIII», y se remite al paradigma a través de la palabra hebrea usada en la Biblia para referir el tabernáculo: la presencia divina manifestada en la «tienda» itinerante de las tribus elegidas. Tras el Éxodo, la tienda se fija en Jerusalén como "estancia perenne del Todopoderoso». El autor recorre también la Septuaginta y su crítica filológica en busca del término griego que traduce esta «tienda» y connota el sentido de permanencia de lo que la Vulgata llama tabernaculum: la imagen del tabernáculo celeste, hecha por los hombres, que «imita» el «lugar de la presencia divina» en el Nuevo Testamento.

En resumen, el tabernáculo barroco muestra y significa el epicentro de un culto de tradición judeocristiana. Su apariencia, gigantesca y rica, "consuela» a los fieles en el siglo XVIII con la imagen de la «inhabitación permanente». Según esta interpretación, la nueva catedral salmantina, configura- 
da en torno a su sagrario, era un escenario litúrgico que concatenaba dogmas eclesiásticos para sostener «la apoteosis de la fe» en la Religión católica. Frente a aquel artefacto, en palabras del autor, «la presencia se comprende a modo de confesión de fe, puesto que presupone como condición previa la existencia, el encuentro con la realidad divina y la historia común».

De esta manera se sintetiza en el libro una «obra» que «recrea en clave inmanente una realidad creída» en el «teatro de la fe». Se trata la obra en términos de arte religioso, objetos que procuraban estimular una «mirada metafísica» y la creencia en la realidad administrada a través de sus imágenes. Así Jose M. Martínez Frías ha recordado el Imagen y Culto de Hans Belting en el prólogo a esta Escenografía, pues ha trascendido los métodos formalistas, documentales, el análisis estilístico y la atribución de la autoría, en una crítica al positivismo de la historia del arte.

Elena Muñoz Gómez

Universidad de Salamanca 